\title{
Union Library Catalogue: Services, 1950. Quo Vadis?
}

Miss Sherwood is Consultant and Miss Campion, Director, the Philadelphia Bibliographical Center and Union Library Catalogue.

$I^{2}$ I950 a total of $\$ 118,386$ was spent in operating the five major union catalogs and bibliographical centers of the United States, i.e. The Union Catalog Division of the Library of Congress, the Union Library Catalogue of the Philadelphia Metropolitan Area, the Pacific Northwest Bibliographical Center, the Bibliographical Center for Research at Denver, and the Union Catalog at the Western Reserve University Library in Clevelahd. Since the $\mathbf{I} 942$ survey $^{1}$ the services of these organizations have been thrice examined in College and $R e$ search Libraries. ${ }^{2-4}$ One current trend in library philosophy today toward centralization of information at the national level tends to regard regional centers as superfluous. ${ }^{5}$ However, the Leigh report recommends increased use of regional bibliographical centers to provide really adequate public library service. ${ }^{6}$ Certainly a re-evaluation of the work of these existing regional catalogs is timely. All five offer a variety

${ }^{1}$ Downs, Robert B., ed. Union Catalogs in the United States. Chicago, ALA, 1942.

${ }^{2}$ Regional Library Centers Today: A Symposium. College and Research Libraries, 8:54-63, January, 1947.

Regional Library Centers Tomorrow: A Symposium. College and Research Libraries, 8:243-51, July, 1947. 4 Esterquist. Ralph R. "Regional Library Centers, 1946-47." College and Research Libraries, 9:215.20, Julv. 1948 .

5 Hessel. Alfred. A history of libraries. $\mathrm{Tr}$. by Reuben Peiss. Washington, D.C., Scarecrow press, 1050. P. 121 .

'Leigh. Robert. The Public Library in the United States. New York, Columbia university press, 1950. p. 160 . of bibliographical services to a broad clientele in diversified geographic areas. Each is hard pressed for financial support under present inflationary conditions. Are these union catalogs worth the expenditure involved? Do they serve their regions adequately? Should all regional centers be abandoned and the bibliographical services which they render transferred to the national level at the Library of Congress? Union catalogs, which way?

In order to obtain the latest statistics and information on services rendered as a basis for this study, each catalog completed a lengthy questionnaire. A study of their replies may aid in determining satisfactory answers to these questions. No study of union catalogs would be complete without including the National Union Catalog whose very size, age and broad national services have set the pattern on which regional catalogs are based. The four regional union catalogs discussed here were chosen because of their similarities in founding, purpose and growth: all were initiated in the depression years with WPA and foundation grants; all have been continued under local auspices; all serve as a center of bibliographical inquiry within their respective regions.

\section{Location Service}

The primary function of union catalogs is the location of books, periodicals and other printed materials within, or outside the region in which they are located through the medium of a single huge author 
file, whose maintenance and control is their primary responsibility. Service statistics reported for this study vary in detail from one catalog to another. To facilitate the comparative remarks throughout this discussion, each center, or catalog, will be referred to by the name of the city in which it is located. Denver received the most requests, followed by Philadelphia, Washington, Seattle and Cleveland. A total of 43,419 requests for all catalogs, including an estimated 3000 personal visitors to $W$ ashington, resulted in a total of 197,555 items searched, including an estimated 100,000 titles searched by the 3000 personal visitors to Washington. Of this number I 52, I 44 items were located, representing a 77 percent successful search (assuming that 77,000 of the items searched by the 3000 personal visitors were found). Philadelphia falls below the average with 55 percent of the items located in 1950 due to the unprecedented number of items checked for persons outside the region for materials almost entirely nonexistent within its area. Philadelphia's normal average is between 65 and 70 percent. Requests come to four of the catalogs mostly by mail, while Philadelphia's requests are 85 percent by telephone.

\section{Clientele Served}

Denver and Seattle keep no detailed statistics on the source of their requests. However, they both report that their clientele is almost entirely academic. Washington's services are primarily academic in nature with a three percent of its total inquiries coming from industrial organizations. Ninety-nine percent of Cleveland's requests are from academic institutions with? a surprising less than one percent from industry. Philadelphia is an exception in that 25 percent of its inquiries are from industrial firms in the area, and this percentage is increasing annually. Seattle and Denver because of their geographical locations may not have the increasing industrial demand as it exists in Philadelphia. Washington, of course, serves all governmental research organizations.

Denver and Seattle not only locate material, but they also arrange for, or actually execute the inter-library loan for each title. Seattle reports that 99 percent of their I0,077 requests were for actual loan transactions which they executed successfully. Because of the large geographical areas covered by these centers, their inter-library loan activity is of major local importance. The smaller number of libraries included in these two union catalogs and the great distances between them have resulted in a system which operates with facility and answers a major need. Cleveland and Philadelphia do not engage in this activity at all. Philadelphia acts as a routing agent for five libraries distant from the University of Pennsylvania Library. This system was developed only as a time-saving measure for the Philadelphia Union Library Catalogue and the University Library.

Inquiries from one union catalog to another seem rather slight. Most inquiries are directed from the regions to Washington. But for 1950, Washington reports only 100 requests from union catalogs, of which $7 \mathrm{I}$ came from Philadelphia. The majority of Philadelphia's requests to $\mathrm{W}$ ashington were for current, technical literature needed by industrial firms. Usually this material must be circularized by Washington, as a large percentage of it does not appear in its union catalog. This is a slow process for an industrial firm which usually wants tomorrow's publications today. Therefore, Philadelphia has built up a large variety of technical reference tools particularly union lists of periodicals from all sources to eliminate the necessity of circularizing. Phila- 
delphia offers to have a search made in Washington for any item not located in its own files. Almost all Philadelphia regional requests to $W$ ashington are routed through the center. Only Denver and Philadelphia check the Weekly List of Unlocated Research Items issued by Washington. This task is the sole responsibility of Philadelphia for the entire area, and it is not duplicated by any other library. The University of Washington library checks this list against the Seattle catalog.

\section{Tools}

Washington quite naturally has the largest bibliographical reference library. Philadelphia has a well-rounded selection of general indispensable tools including the LC Author and Subject Catalogs; the British Museum Catalogue of Printed Books; CBI; Publishers' Weekly; ULS; Besterman's World Bibliography of Bibliographies, to mention only a few, as well as a large collection of union lists of serials. Denver has the British Museum Catalogue; ULS; Books in Print with all other specialized tools available in the Denver Public Library. Cleveland and Seattle depend entirely upon the bibliographical tools in the libraries in which each is housed. This is a logical and economical arrangement.

\section{Bibliographical Services}

There is a wide difference in policy in checking lengthy bibliographies for individuals or institutions. Washington will not check long lists due to the pressure of regular duties. Philadelphia checks lengthy lists for persons or institutions outside the area, provided that the work is of a serious nature, and that the Center is the single organization in the area to do the checking. The latter stipulation is made to avoid duplication of effort by the libraries within the city. Denver and Cleveland check bibliographies for persons within the region only. Cleveland checks lists only for other union catalogs, provided such lists are short. Seattle has no geographic limitations, but specifies that the lists be short. Only three centers compile subject bibliographies. Philadelphia maintains a special catalog of subject bibliographies known as the Z-file. From this and current sources, bibliographies in general fields of knowledge are prepared for clients upon occasion. Philadelphia refuses to compile scientific or technical bibliographies because its staff members are not subject specialists, referring such requests to the library specializing in the subject desired. Seattle and Denver report the compilation of a few bibliographies.

\section{Special Services}

Denver and Philadelphia supply LC or Dewey classification numbers to libraries which request this service. Philadelphia assists many industrial libraries in the cataloging and classifying of their entire collections. Only Philadelphia specializes in the identification of author, publisher, price, date of publication and publisher's address, etc. for book stores, libraries, and individuals. This service to the book and publishing industry in the metropolitan area amounts to 7 percent of the center's total services.

Washington in conjunction with its Photoduplication service provides the national union catalog searching service for unfilled Library of Congress card orders and supplies photostatic copies of union catalog entries. Philadelphia notifies any client interested in a newly published title of the locations of first copies as soon as received. About 200 notices are sent each year, primarily to technical libraries for recent scientific works. Book appraisal, the value of old imprints, or the critical evaluation of new books is not a function of any of the centers. 


\section{Regional Cooperation}

There is no organized program in any of the four regions to avoid duplication in purchasing of expensive materials. Washington cooperates with the Library of Congress to avoid the latter's duplication of expensive materials. Filing cards for all Farmington Plan acquisitions in the $\mathrm{Na}$ tional Union Catalog helps prevent largescale duplication. Denver states that cooperative buying occurs by consulting holdings in the region, but does not explain how this is done. Three libraries in Philadelphia consistently check the local union catalog for location of duplicate copies before making expensive purchases. This practice occurs primarily in the case of early American imprints and expensive reference tools. Seattle and Cleveland report very little such practice. Philadelphia is consulted frequently concerning plans for the withdrawal of materials. Frequently, transfers of whole collections are made between libraries as a result of this intelligent use of the catalog. This practice has probably been encouraged through the duplicate exchange service operated by Philadelphia. During 1950 four lists of materials were issued. These contained about 1000 titles available in approximately 30 libraries to any single library assuming the transportation charges. Formerly a depository for duplicate materials for the entire area, Philadelphia abandoned this practice as too expensive and substituted the issuance of lists. Hundreds of issues of journals are exchanged among the libraries of the area as well as among libraries outside the state anxious to receive earlier numbers of technical periodicals. Seattle checks lists of proposed discards for last copies in the area, and also advises and arranges for the last copies to be sent to various libraries for preservation.

\section{National Cooperation}

Only the holdings of Philadelphia and Cleveland are included in the National Union Catalog. Both these centers forward current accessions to Washington at regular intervals. It is proposed to extend the National Union Catalog's coverage to include all regional union. catalogs. ${ }^{7} \mathrm{Co}-$ operation in checking the Weekly List of Unlocated Research Items is another example of cooperation with $\mathrm{W}$ ashington.

\section{Special Files}

Washington maintains four special files: Microfilm clearing house for long runs of newspapers, serials and manuscripts; Index to special collections in U.S. libraries; Special file of Festschriften; and a Special file of almanacs. Denver has started a file of microfilm holdings of libraries within its region and maintains a file of early theses and a file of subject specialists and translators in the area. Cleveland has a file of masters' theses from several Ohio colleges. Seattle has no special files. Philadelphia maintains a union catalog of the microfilm holdings of the major libraries of the U.S. and Canada; and the $\mathrm{Z}$-file of subject bibliographies.

\section{Publications}

Denver issues a regular Bulletin, Newsletter and Annual Report and has published seven subject bibliographies, 1937-1939. It has plans for two additional publications; one; a survey of photoduplication services and the other, a bibliography of bibliographies of serials, newspapers and directories. Seattle issues a news article in each issue of the Pacific Northwest Library Association

7 Downs, Robert B. "Report and Supplementary Report of the National Union Catalog and Related Matters." Library of Congress Information Bulletin, Aug. 9-15, 1949. Appendix. 
Quarterly. Cleveland has no publications. The National Union Catalog has issued lists and bibliographies consistently since 1933. Its most important is the annual Select List of Unlocated Research Books, 1937 to date. Philadelphia, in the other extreme, has been a prolific publisher of reports, studies and newsletters during its fifteen years' service. The latest, and probably best known, is the Union List of Microfilms, revised, enlarged and cumulated edition, Edwards Brothers, 195I. Its Newsletter appears regularly five times a year and it is sent to libraries throughout the United States and abroad.

\section{Estimate of Services Rendered}

The questionnaire on which this study is based asked for a frank opinion from each center: "Do you feel that local research is using the facilities available at the respective centers adequately?" A surprising number of affirmative replies were received. Denver gave an unqualified negative answer. Philadelphia definitely feels there is a much more intelligent purpose for its facilities in the field of cooperative effort of all libraries within the region. The whole field of cooperative acquisition, withdrawals and the development of holdings in specific subject fields could be more fully developed to result in a better use of the tool at hand. Philadelphia is not satisfied that all industry uses its services as advantageously as it could. Considering the phenomenal increase in the demands for its services, perhaps Philadelphia is impatient. Although Washington feels its services are being used adequately, the total figure for requests seems small in comparison with those received by the regional centers. Of course, the regional centers over the years are diverting increasing numbers of requests away from Washington.

\section{Organization and Financial Support}

A careful study of the staff and expenditures on the accompanying table reveals that the National Union Catalog, operated solely on government funds, has the largest income, $\$ 77,000$ and a staff of 18 ; Philadelphia, a non-profit corporation, has the next largest income, $\$$ I $_{5}, 200$ and a staff of 5; Seattle, which is operated by the Pacific Northwest Library Association, has an income of \$14,306 and a staff of 3 full time and 3 part time; Denver, a non-profit corporation, has an income of $\$ \mathrm{IO}, 468$ and a staff of 6 ; and Cleveland, operated by the Western Reserve University Library, has an income of $\$ 4,233$ and a staff of 2 .

Philadelphia, Denver and Seattle are cooperative enterprises supported by annual subscriptions of the institutions which they serve. Philadelphia receives 48 percent of its income from cooperating libraries; 27 percent from industries; and 25 percent from individuals. Denver receives 68.5 percent from cooperating libraries; 8.5 percent from industry and 23 percent from individuals or state and municipal grants. Seattle is supported 100 percent by the libraries of the Pacific Northwest. All five centers admit that if they had more income, they could expand their services. At the same time the regional centers find that while the demand for their services is in. creasing rapidly, their income increases very slowly.

\section{Plans for the Future: Conclusions}

\$I I 8,640, miserly sum though it may be, produced 152,555 answers for 43,419 inquirers in 1950 , to say nothing of the filing of $1,307,312$ cards and the centralizing of hundreds of other bibliographical shortcuts which many research and industrial libraries cannot supply independently. This wide variety of services is acclaimed by the 
TABLE I

DATA CONCERNING UNION CATALOGS

\begin{tabular}{|c|c|c|c|c|c|c|}
\hline \multirow{2}{*}{$\begin{array}{l}\text { Factors and } \\
\text { Activities }\end{array}$} & \multicolumn{5}{|c|}{ Union Catalog Locations } & \multirow{2}{*}{$\begin{array}{l}\text { I950 } \\
\text { Total }\end{array}$} \\
\hline & Washington & Philadelphia & Denver & Cleveland & Seattle & \\
\hline Libraries Included & $1, \infty 0^{a}$ & 171 & $5^{2}$ & 43 & 39 & I, 305 \\
\hline $\begin{array}{l}\text { Includes an LC Deposi- } \\
\text { tory }\end{array}$ & Yes & No & Yes & No & Yes & \\
\hline Cards in File & Io, 190,898 & $4,5 \infty, \infty \infty$ & $x^{b}$ & $2,500, \infty 00$ & $\mathrm{I}, 300,104$ & \\
\hline $\begin{array}{l}\text { Titles (Excluding L C } \\
\text { Depository) }\end{array}$ & $6,350, \infty 00$ & $3,5 \infty, \infty \infty$ & $x^{b}$ & $x^{b}$ & $x^{b}$ & \\
\hline Requests Received & $8,270^{\circ}$ & II, 2 II & I I , 286 & 2,575 & 10,077 & $43,4^{19}$ \\
\hline Items Searched & $117,272^{d}$ & $3 \mathrm{I}, 4^{\mathrm{I} 2}$ & $30,45^{6}$ & $8,33^{8}$ & 10,077 & 197,555 \\
\hline Items Found & $90,287^{\mathrm{g}}$ & $17,66 \mathrm{I}$ & $27, \infty 0^{\circ}$ & 7,189 & $10, \infty 07$ & I $52, I_{44^{g}}$ \\
\hline $\begin{array}{l}\text { Accessions Received in } \\
1950\end{array}$ & 959,140 & II 6,545 & 65,109 & $8 \mathrm{I}, 304$ & 85,214 & $1,307,3^{12}$ \\
\hline Withdrawals & $5, \infty \infty^{d}$ & 3,500 & 5,763 & 6,402 & 12,351 & 33,016 \\
\hline I950 Income & $\$ 77, \infty 00$ & $\$ 15,200$ & $\$ 10,468$ & $\$ 4,233$ & $\$ 14,306$ & $\$ 121,207$ \\
\hline I950 Expenditures & $\$ 77, \infty 00$ & $\$ 16,171$ & $\$ 8,686$ & $\$ 4,477$ & $\$ 12,052$ & $\$ 118,640$ \\
\hline $\begin{array}{l}\text { Staff: Professional } \\
\text { Non-professional }\end{array}$ & $\begin{array}{l}9 \\
9\end{array}$ & $\begin{array}{l}2 \\
3\end{array}$ & $\begin{array}{l}3 \\
3\end{array}$ & I & $4^{f}$ & $\begin{array}{r}16 \\
\quad \times 20 \\
\end{array}$ \\
\hline
\end{tabular}

a. Partial holdings only.

b. Unknown.

c. Includes an estimated 3000 visitors.

d. Includes an estimated roo,000 titles searched by above 3000 visitors.

e. Estimated total.

f. 3 Part time.

g. Allowing for $77 \%$ success in 100,000 titles searched by 3000 visitors.

clientele enjoying them in each of the five areas represented. Existing services, therefore, seem to be excellent in so far as they serve their immediate areas. The expenditures do bring in a worthy return and each center seems to be serving its area adequately.

Ralph E. Ellsworth, an exponent of the current philosophy to centralize information at the national level, states ". . . to be specific I maintain that as things now stand in the year 195I (and of course everybody agrees with this position) there is little need for pursuing the idea of regional bibliographical services, organizations and tools, although ten years ago there was such a need. But book handling on the other hand can be done on a regional basis. It is the job of our bibliographical tools and services to tell us what books exist relevant to the task at hand."

It is interesting to contemplate the outcome of 1950's 43,419 inquiries concerning 197,555 items had they all been directed to Washington. The inquirers would most probably have received adequate answers, but much more slowly than at present. Could Washington absorb all the bibliographical services which regional centers render locally: If not, would the local libraries of the regions be willing to absorb

\section{(Continued on page IIO)}

8 Verbatim statement made at the University of Pennsylvania Symposium. Changing Patterns of Scholarship and the Future of Research Libraries. May 8, r951. 
lished since January of 1950 , also has a section devoted to republications. These and other improvements are still no substitute for the knowledge gained by experience in using the Official Records, nor will they be of much value without such experience. Nevertheless, they are indicative of the United Nations' willingness to disseminate knowledge of its work as broadly as possible. They help to make it possible for United Nations documentation, in spite of its bulk and complexity, to be fitted into a medium-sized library without demanding a disproportionate slice of budget and stacks. And even a limited collection of these documents, aided when necessary by interlibrary loan from one of the depository libraries, can be an extremely valuable possession at a time when world wide understanding and knowledge are needed more than they have ever been before.

\section{Union Library Catalogue: Services, I950. Quo Vadis? \\ (Continued from page 106)}

the additional task of supplying these miscellaneous services to the public and industry at large? We doubt it. We feel that the very growth of these services within the four regions justifies their continuance and emphasizes the importance of their consideration in whatever local, regional or other library planning is undertaken.

In conclusion, this study points to a definite need for more careful attention to the potentials and values of the regional centers to the public, college, research and industrial libraries within the area by the libraries themselves. The centers have told and retold their story; they have performed their services in peace and in war, in depression and in inflation. They have set the pace in almost every instance. Are libraries leading the way to better centers, or are they accepting this manna as something quite within the ordinary? How do new staff members come to know and use the bibliographical centers? Do they visit the center, learn from a librarian who understands and uses the center frequently, or are they merely told to "call this number if you don't know the answer."

It is imperative that a concrete program of better, even if somewhat fewer, services to a larger number of institutions and individuals be resolved. Greater cooperation among librarians and business men in the activities of the regional centers should result in progress in solving the current financial needs. Where industry learns that bibliographical services pay in business profits, their financial support is forthcoming. If interlibrary loan is the primary need, such services should be implemented and expedited. If industry has immediate need for technical materials, cooperation should be fostered to produce them promptly. If the National Union Catalog is to be expanded, what other libraries should be included? These are but a few of the problems to be considered, and they vary from center to center. There is a definite need for more community participation in the planning, or mediocrity will certainly result. Now is the time for concerted action. 